\title{
THE RIGHT TO FREEDOM OF EXPRESSION VIS Á VIS PUBLIC INTEREST
}

\author{
PhD Svetlana Veljanovska \\ Faculty of Law Kichevo - "St. Kliment Ohridski” University, Bitola \\ svetlanaveljanoska@hotmail.com \\ PhD Sasha Dukoski \\ Faculty of Law Kichevo - "St. Kliment Ohridski” University, Bitola
}

Professional Paper

doi:10.5937/jouproman4-11876

\begin{abstract}
The right of freedoms of expression is one of the fundamental human rights. This, among other things, is guaranteed by Article 10 of the European Convention for the protection of human rights and freedoms. However, the freedoms of expression is not an absolute right, which means that in some situations it may be restricted, especially if the public interest requires that.
\end{abstract}

Submission of information for media must be in accordance with the human rights of the people who are involved. These rights are guaranteed by the European Convention for protection of human rights and freedoms, by the Constitution and by Laws. Having in consideration that this freedom carries some duties, the enjoyment of this freedom may be based on formalities, conditions, restrictions or penalties, as it is prescribed by law and they are necessary in one democratic society for the purpose of crime prevention, protection of reputation or protection of the rights of other people, for prevention of disclosure of confidential information or for maintaining the authority and independence of the judiciary.

If the courts accept the thesis that somebody has the right to say or write something and it is said in public interest, although it violates the rights of another person, it means that the freedoms of expression prevails over some other rights.

This paper aims to examine the aspect of freedoms of expression, especially in the media and the judiciary, versus the need of protection of the public interest and latest legal decisions that are related to this matter.

Keywords: public interest, freedoms of expression, human rights

\section{Introduction:}

The question about how we treat the right of freedoms expression actually reflects on how we treat the responsibility to insult and defamation. Although the insult and defamation are decriminalized, the Law on Civil Liability for Defamation and Insult adopted in 2012 provides an opportunity for civil liability for insult and defamation ${ }^{3}$.

The sensitivity regarding this question is obvious, having in consideration that the question is closely related to the freedoms of media and to the right of certain things to be said in public interest, which sometimes can conflict the right to protect the honor and reputation of the individual. In fact, defamation and insult, but also provisions which govern them, deal with the care for honor and reputation of a person versus statements made about him/her.

\section{The Role of the Media in Protecting Public Interests}

By definition, media pluralism should enable the public different political ideas and opinions freely and equally to circulate.

\footnotetext{
${ }^{3}$ Law on Civil Liability for Defamation and Insult (Official Gazette of the R.M. no. 143/2012)
} 
That means that each medium should separately try to ensure the so-called internal pluralism in the news, that is to say, to present all opposing opinions and points of view about one topic.

This is very important for the overall democratic public sphere, because the citizens may develop a complete picture and they may form their opinion about the issues of public character by themselves. Conversely, avoiding reporting on certain topics or distortion of the angle by emphasizing only one view creates ideological manipulation of public opinion in long term.

Broadcast media, especially televisions, have great importance in informing the citizens about the pluralism of the views and opinions in the society. They have a legal obligation (Article 61 of the Law on Audio and Audiovisual Media Services), but also ethical obligation (Article 14 of the Code of Journalist of Macedonia) to report for different political subjects unbiased and balanced, and they should not display political leaning in a way that they will favor one view and attack another view.

The institute of Communication Studies $^{4}$ conducted monitoring and analysis of the way televisions report on different political views and ideas on state level, but also on the extent to which they provide access to the political actors to their programs.

Conclusions of this report show that the monitored media may be grouped into two categories:

- televisions which contain construct propaganda and populist discourse in favor of VMRO-DPMNE and the Government

\footnotetext{
${ }^{4}$ REPORT on monitoring of media content through the mechanism for monitoring and response at the Institute of Communication Studies (period: from 23 November to 18 December 2015)
}

- televisions which contain mildly critical or neutral position to the government.

The method used in this study is based on the theories for framing and reporting, which explains how the media frame the themes of social and political life on which they report, and how they shape the journalist's text and give meaning to the events presented in it.

Reporting framework contains four aspects:

$\checkmark$ Theme of informative article - which is included in the framework;

$\checkmark$ Presentation - scope and place of the attachment (photos, quotes, title and subtitles);

$\checkmark$ Cognitive landmarks details about what is included in the framework;

$\checkmark$ Affective landmarks - the tone of reporting.

This research shows how much the media respect the professional standards in reporting about the political actors defined in the Code of Journalists of Macedonia and the codes of the international organizations.

In general, the analysis provided answers to the following questions:

1. What kind of approach do the media have and to what extent they respect the standards for impartial and balanced reporting?

2. In which way does the media represent (frame) the political actors during the election campaign?

3. Do the media respect the rule of comprehensive information (using the sources)?

4. Do the media apply frames which encourage and reinforce stereotypes, that is to say, whether they apply discriminatory speech or hate speech towards groups and individuals? 
The analysis shows that there is a great similarity in the framework constructed in the news of the Public service and commercial media - Sitel, Alfa and Kanal 5 . There is a huge overlap in the selection of the topics, sources and the angle of the elaboration of the topics. Even synchronized broadcast of stories on the same subject and with same speakers can be noticed. This means that it is possible that the program on these televisions is coordinated by a single source.

However, among these televisions there is a difference in the ways in which each of them uses propaganda tools and populist discourse. Sitel, Alfa and Kanal 5 lead in favoring the ruling party VMRODPMNE, and the whole production of the Public service converts the news in party and governmental bulletin, platform on which VMRO-DPMNE and DUI may freely advertise their activities. These televisions have a huge production of stories related to the politics and political actors: Sitel (347), Alfa (318), Kanal 5 (263), MTV1 (273) and MTV2 (207).

The fact that the vast majorities of these stories are partial to VMRO-DPMNE or demonize SDSM (or both) shows high level of aggressiveness in the creation of the antagonism to the political scene. Leaving the basic standards is in direct contradiction with the self-regulatory principles engraved in the Code of Journalists. Half of the Articles of the Code are breached, especially the Article 14 which refers to the imperative that 'the journalist must ensure a professional distance from the political subjects.

The second group of media according to this analysis is the media where one can notice a neutral or mild approach - Telma, Alsat M, 24 Vesti and TV21. It is shown that these media are trying to resist the hegemonic discourses of the ruling parties and also they are trying to resist the topics that circulate through the progovernmental media. Among them, they generally respect the professional rule to present, conditionally said, also 'the other side' in the media stories.

This means that these televisions provide the so-called internal pluralism in the news, and they try to present as many conflicting opinions and views of one subject as they can. However, in some of the stories on these televisions it can be noticed that there is a tendency of violation of the professional standards in terms of the spectrum of consulted sources. However, there are stories on these televisions which have only one source. This practice is not systematic in the selected period and it is not misused in the direction of favoring or demonization the political subjects.

These obtained research data refer to a specific period of time. However, although we cannot generalize, it can be concluded that there is polarization in the media space in our country, and the public interests are observed from an aspect which is located on a specific target group: ruling parties, parties that are in the opposition, other target groups (business sector) and their interests are over the public interest in the country.

\section{New Regulations for Protection of the Public Interests}

The Law on Protection of Privacy and the Law on Protection of Whistlers were adopted in the Assembly of the Republic of Macedonia, in November 2015.

The adoption of these two laws is initiated by the occurrences in the society connected with the discovery of the affair for mass illegal interception of communications. The two laws deal with areas which directly affect the public interest, one in terms of protection of privacy, and the other in terms of protection of the people who may show actions that can jeopardize the fundamental rights and freedoms of the citizens and of the business subjects. 


\section{- Law on Protection of Privacy}

This law aims to regulate the issues of privacy of the citizens of the Republic of Macedonia from the materials which arise from the illegal interception of the communications in the period from 2008 to 2015. It imposes obligation for the holders of such kind of materials, such as: ban for possession, processing and public publishing, if they provided these materials through illegal interception of communication.

All those people who possess materials obtained by unlawful interception of communications should hand them over in the legally prescribed period of 20 days after the enactment of the law. This law envisages sanctions for all those who will publish the previously mentioned materials or will show the content of the materials to other people, except when it is a conversation or information of public interest.

There is an interesting fact that this law provides obligation for the competent court, which will act upon it, to respect ECHR (European Convention of Human Rights) as well as to respect the practice of the European court of Human Rights. The law foresees two limits, one in the scope of its application and the other in the scope of its duration.

Namely, the stipulations of the law do not apply to the published materials which are obtained through unlawful interception of the communications until July 15, 2015. Also its implementation begins 6 months after its publication in the Official Gazette in the Republic of Macedonia.

Formulated like this, the Law on Protection of Privacy is unclearly constructed and it is completely confusing. In addition, it does not correspond with the Constitution of the Republic of Macedonia because it provides updates that are contrary to the Constitution. Respect of the ECHR is already provided with the Article
98 from the Constitution of the Republic of Macedonia. However, the part of this law which refers to the respect of the court practice of the Court in Strasbourg is contrary to the same Article of the Constitution, according to which 'The courts judge on the basis on the

Constitution, the laws and the
international contracts ratified in accordance with the Constitution'.

In the part of the public interest the Law does not provide any clarity or precision which in this case would define the public interest, which makes it even more confusing and hardly applicable in the work of the courts.

\section{- Law on Protection of the Whistlers}

The aim of this Law is to regulate the protected reporting, the rights of the whistlers, as well as the behavior and the obligations of the institutions, that is to say, of the legal entities regarding the protected reporting and providing protection to the whistlers. This Law is important in terms of protection of the public interest, especially because the protected reporting is defined as reporting which transfers reasonable suspicion or knowledge that something is done, that something is completed or a criminal or other illegal or unacceptable behavior which affects or threatens the public interest is likely to be executed.

This Law clarifies that the term public interest means protection of the fundamental rights and freedoms of the people and the citizens, recognized by the international law and determined by the Constitution of the Republic of Macedonia. It also means prevention of health risks, defense and security, prevention of environment and nature, protection of the property and freedom of the market and the entrepreneurship, rule of law and prevention of crime and corruption. 
The whistler is provided with protection and is guaranteed with anonymity and confidentiality to the extent and to the point to which he/she wants it. The right to anonymity may be restricted to the whistler with court decision, and the whistler shall be informed about that forthwith.

The Law also provides data protection and protection of the identity of the whistler, so that disclosure or enabling disclosure of the identity of the whistler is forbidden, except if it is required by a court decision.

Although this Law regulates the protection of the whistlers to a great extent, it contains several provisions which may be problematic if applied in practice.

The whistler performs protected internal reporting to the institutions, that is to say, to the legal entity for which there is a suspicion or knowledge that they perform or will perform criminal action or illegal behavior.

On the other hand, the whistler performs protected external reporting to the Ministry of Internal Affairs, to the competent Public Prosecutor's Office, to the State Commission for Prevention of Corruption, to the Ombudsman of the Republic of Macedonia or to other competent institutions.

Especially problematic is how the public reporting is regulated, that is to say, making publically available information regarding the knowledge that a criminal action $^{5}$ is performed, is being performed, or will probably be performed. In this type of reporting, the protection for the whistler is provided only in case when the whistler already performed the first two types of reporting (internal and external).

\footnotetext{
${ }^{5}$ Hereupon, this action may violate or endanger the life of the whistler, or the life of a close person to the whistler, health of the people, security, environment, huge damages, that is to say, if there is a potential danger of destruction of evidences.
}

If the whistler reveals information without having performed these two types of reporting previously, then he/she doesn't have the right to protection of violation of the right of employment in the institution where the reporting was performed, and also the whistler does not have a right to judicial protection at the competent court.

This is not in accordance with the principles for protection of the whistlers, which many countries have incorporated in their jurisdictions. According to these principles, determined by Transparency International $^{6}$, the whistlers should enjoy protection also in the situations when they perform public reporting (in the media, in the civil society and in other organizations).

\section{Public Interest in the Judicial Institutions in the Republic of Macedonia}

Civil courts rarely encounter legal issues in which public interest is subject to decision. It is a general conclusion that in cases where there is no involvement of any public official, the court consistently applies the practice of ECHR and EC. It is a fact that if some public official is involved in the procedure, the judges allow faster development of the procedure and shorter deadline for scheduling the hearings, which enables faster completion of some of the cases.

That could be treated as disrespect of the European Convention and the practice of the court in Strasbourg, whereupon the freedoms of expression in Macedonia is seriously jeopardized, and the question about (in) dependence and (luck of) quality of the judiciary in the country is imposed. ${ }^{7}$

\footnotetext{
${ }^{6}$ International Principles for Whistleblower Legislation, Best Practices for Laws to Protect Whistleblowers and Support Whistle blowing in the Public Interest.

7 See the event: Mijalkov against Fokus; Nikola Gruevski against Tito Petkovski; DHC against Popovski; Igor Serafimovski against Ljubisha
} 
Unlike civil courts, the administrative courts often encounter issues about public interest in the scope of their work. The reason for that is the fact that in all cases which are conducted in the administrative courts, the country, that is to say, the executive power through the public bodies and organizations, both on national and local level appears as defendant. Because of this, the role of the administrative courts is obvious, when it comes to controlling and correcting the implementation of measures and activities, which arise from the needs imposed by the public interest in different spheres of social life. ${ }^{8}$

The carried analysis clearly shows that public interest most often is found in the cases of expropriation and denationalization. This means that the administrative courts appreciate the public interest in the decisions of the administrative courts in the Republic of Macedonia only within the Law on expropriatio $^{9}$ and the Law on Denationalization $^{10}$, not going into broader interpretation of them in the deciding cases.

For example, in Verdict A-2. no. 2079/2011 from 09.01.2014 from the Administrative Court, in which the individuals A.F, I.F and P.K are plaintiffs, while the Minister of Finance in defendant, and subject of the administrative dispute was real return of the taken land by expropriation in 1947, the Administrative Courts rejected the appeal of the plaintiffs.

Arsic; Sasho Jakimovski against Snezhana Lupevska and the Company for production, marketing and services Trinity Plus Production LTD Skopje; and others.

${ }^{8}$ Because of the growing need for bigger control of the legality in the actions of the executive power, in 2006 the Administrative Court of the Republic of Macedonia was formed, as first and only specialized court in the judicial system with general jurisdiction.

9 Article 9 from the Law on Expropriation, Official Gazette of the Republic of Macedonia no. 24/2013

${ }^{10}$ Article 10 from the Law on Denationalization,

Official Gazette of the Republic of Macedonia, no. 20/98
The reason for rejection of the complaint was that the opinion of the Administrative Court was that the decision of the Ministry of Finance was correct. The decision was not to return the requested property completely to them, because in that part of the land, a realization of public interests was projected, that is to say, a primary school and streets were planned to be built there.

Despite the fact that the plaintiffs challenged the decision of the Minister of Finance, with the argument that the purpose of seizure was not realized and that the land was not a built up land, the Administrative Court concluded that because of the "planned building of the primary school and streets, there is a legal obstacle for returning the property which is a subject of claim for denationalization., ${ }^{11}$

The Administrative Court in this case valued only the legality, but not the essence of the legal action, which can be seen from the fact that it does not checked whether the object which is of public interest is built, as well as when it would be built.

Similarly, to the Administrative Court, the Supreme Administrative Court when dealing with complaints lodged against the decisions of the Administrative Court also seeks the public interest to be determined by the state authority.

Unlike regular courts, the Constitutional Court acts in very limited ambit, but its decisions have general effects; that is to say, they apply to all citizens and legal entities in the Republic of Macedonia. Because of this the attitudes and the opinions, which the Constitutional Court has taken in its decisions, are interesting in relation to the matters that directly or indirectly interfere the public interest.

\footnotetext{
${ }^{11}$ VerdictA-2. No. 2079/20122 from 09.01.2014 from the Administrative Court
} 
Namely, the Constitutional Court in the Decision C. no: 120/1998-0-1 from 10.03.1999, after the initiative of the Association for Protection of Interests of the Owners of the Seized Properties Skopje, annulled the Article 1, Article 9 paragraph 1 from the items 5 and 6, Article 11 paragraph 1, Article 22 paragraph 2, Article 23, Article 28 paragraph 1 and paragraph 2, Article 29, Article 34, Article 2 in the part 'there is no interest calculated for them' and Article 38 from the Law on Denationalization $^{12}$ as unconstitutional.

Namely, the Constitutional Court considered that these legal provisions, concerning the provision of compensation for property which is not in public function without specific determination of the public interest, are contrary to Article 30 of the Constitution of the Republic of Macedonia, which envisages protection of property.

In the part where there is an explanation of public interest, the Constitutional Court took pose that 'the public interest is in close correlation with the term general interest and implies clearly determination of the corpus of the objects on which one can establish such kind of relationship. That interest cannot be covered by a single law, and when it comes to objects, its determination should clearly define the objects that require exercising the right on such objects from a wider range of legal entities or other users. Furthermore, it must be clearly seen why these objects have such character.

It can be a particular object, but it also can be globalized on series of objects or such interest determined by type. Starting from that and moving towards the constitutional framework in terms of public interest, we can conclude that with this decision the ownership of the object cannot be returned, but compensation can be given for the property that is in public function without special determination of

\footnotetext{
${ }^{12}$ Law on Denationalization, Official Gazette of the Republic of Macedonia no. 20/98
}

the public interest, as provided in Article 9, paragraph, items 5 and 6 from the Law, the right of ownership is restricted, so the court decided that these provisions are not in accordance with the Article 30 from the Constitution. $^{13}$

However, the Constitutional Court is not always clear and precise in its opinions when it comes to public interest. Namely, in the decision C. number: 27/2013-0-1 from 16.04.2014, the Constitutional Court denied the request of N.S - the president of AJM (Association of Journalist of Macedonia) and the request of the journalists N.S, F.F, S.L, B.B and T.A represented by the Law Office Mendarski from Skopje, for protection of the rights and freedoms stipulated in Article 110, paragraph 3 from the Constitution of the Republic of Macedonia, for violation of the freedom of public expression. ${ }^{14}$

The appellants are journalists that together with other colleagues attended and followed the session in the gallery of the parliamentary hall of the Assembly of the Republic of Macedonia on 24.12.2012, where the Budget for 3013 was supposed to be adopted. At the moment when the situation escalated in the parliamentary hall, the parliament's security expelled all the journalists, but the journalists that rebelled while removing them, were forcibly expelled by using a physical force. After this incident, the AJM and the appellants addressed the Ministry of Foreign Affairs and the Ombudsman, but also at the end they addressed the Constitutional Court for protection of the freedom of public expression, which is provided in a separate procedure in the Article 110, paragraph 3 from the Constitution of the Republic of Macedonia.

\footnotetext{
${ }^{13}$ Decision of the Constitutional Court of the Republic of Macedonia, C. No: 120/1998-0-1 from 10.03.1999

${ }^{14}$ Decision of the Constitutional Court of the Republic of Macedonia C. number: 27/2013-0-1 from 16.04.2014
} 
The Constitutional Court accepted the request of the appellants and decided to reject it. In the explanation of the decision, the Constitutional Court showed contradictory view-points and opinions, because at first stated that 'the act of expelling the journalists from the gallery of the parliamentary hall represents interference of the right of the journalists to perform their work freely and to inform the public' - so bellow in the same decision to state that 'This would imply that only the presence of the journalists in the hall and the direct transfer does not make one session a public session, because there are several ways in which the Assembly allows transparency in its work, and they were applied in that particular event'.

The decision to refuse the request is made by the majority of the votes and the dissenting opinion of one of the constitutional judges. According to it, the transfer of information for all matters of public interest in a way and in accordance with its obligations and responsibilities is a right of the journalist and that otherwise the journalism wouldn't be able to perform its role of 'public supervisor', critic and guardian of the progress and democracy. ${ }^{15}$

\section{Conclusion}

From the above analysis of the activity of the media and the courts in the Republic of Macedonia, it can be concluded that in the part for protection of public interests there is inconsistent behavior among the judges, especially in cases for calumny and insult where senior government officials are involved. The pressure that the judges have is noticeable, not only for the outcome of the dispute, but also for the duration of the proceedings and the awarded high amounts for compensation of intangible damage.

\footnotetext{
${ }^{15}$ Decision of the Constitutional Court of the Republic of Macedonia C. Number: 27/2013-0-1 from 16.04.2014 (Dissenting opinion of the judge Natasha Gaber - Damjanovska)
}

Most of the procedures for defamation and insult are against journalists, which suggests that there is a tendency of influencing journalists when reporting on public officials in cases when they investigate topics that are of public interest and which can make their reputation questionable. In terms of the awarded compensation for intangible damages, which are extremely high, there is a question whether they are rational from the aspect of protection of the reputation, in terms of whether they are a compensation for damage or a punishment that is used as tool for discipline.

From the presented objects there is formalism by the executive authorities in the application of legal provisions regulating the public interest. In none of the analyzed cases it is not explained what does the public interest mean in this case.

In general, the courts practice the legal regulations. However, the objectivity in terms of acceptance of this evidence is presented and it plays a huge role in bringing the final judgment.

For the public interest, it should also exercise control over it, which is contained in international documents. It must not be forgotten that: the legislature is the one that is trying to shape and define the public interest, the executive authority should implement and protect it, while the most complex and perhaps the most difficult role is to be left on the judiciary because it should measure and evaluate the public interest, and if the executive authority implements the public interest should also control it.

\section{References}

- G. Kalajdziev, Human rights - Framework for the European Criminal-Procedural law, in the Collection in 'Iustianus Primus Faculty of Law' in Skopje, in honor of the professor GorgjiMarijanovikj, Skopje, 2011, p. 115-128

G. Kalajdziev, For the Combat of the Organized Crime and the Legal State, Foundation Open Society - Macedonia 

2014

- S. Veljanovska, Judical System, Kichevo

- M. Nowak, International Convenant on Civil and Political Rights: CCPR Commentary, Engel, Kehl/Strasbourg, 1993, At. 14, No. 24.

- P. De Hert, Balancing Security and Liberty Within the European Human Rights Framework. A critical reading of the Court's case law in the light of surveillance and criminal law enforcement strategies after 9/11, Utrecht Law Review, 2005, https:// www.utrechtlawreview.org/articles/ abstract/10.18352/ulr.4/

- S. Dimovski/j. Ilievski/Z. Dimitrievski: Transparency in Criminal Procedures - Handbook for Journalists, 2014.

- D. Gocevski/ F. Ilievska: Deconstruction of the Concept Public Interest in the Republic of Macedonia - (mis) use on behalf of the citizens, Starting report, Institute for Communication Studies, The School of Journalism and Public Relations.

-Monitoring the Court Cases for Insult and Defamation, Centre for Media Development / USAID, March 2014.
-Monitoring the Court Cases for Insult and Defamation, Centre for Media Development / USAID, July 2014.

-Monitoring the Court Cases for Insult and Defamation, Centre for Media Development / USAID, October 2014.

-Monitoring the Court Cases for Insult and Defamation, Centre for Media Development / USAID, December 2014.

-Monitoring the Court Cases for Insult and Defamation, Centre for Media Development / USAID, April 2015.

-Monitoring the Court Cases for Insult and Defamation, Centre for Media Development / USAID, July 2015

-Law on Protection of the Whistlers, Official Gazette of the Republic of Macedonia no.62/2006.

- Law on Civil Liability for Insult and Defamation, Official Gazette of the Republic of Macedonia no. 143/2012.

- Law on Administrative Disputes (Official Gazette of the Republic of Macedonia no.62/2006) 